\title{
Campaigns of Redistribution: Land Reform and State Building in China and Taiwan, I950-1953
}

\author{
Julia C. Strauss
}

Chapter I of this volume has disaggregated how we might think about state capacity as a process that moves from historical origins, organizational (bureaucratic) capacity, political deployment, and performance, with perhaps organizational capacity being the most important. Insofar as the state does not have sufficient resources, a significant and productive presence in society, a trained and professional civil service, and institutional coherence, political deployment and performance are likely to suffer. Yet generating sufficiently capable state organizations is far from automatic; taxes may be difficult to extract, state agents predatory or ill equipped to deal with the challenges they face, societies apathetic or indeed outright hostile to state programs. Since these are exactly the kinds of circumstances in which state-making elites in the developing world find themselves, we need to ask ourselves how nascent and weak state institutions might actually generate capacity to implement initiatives and programs. Is successful or unsuccessful policy implementation simply an indicator of preexisting state (in)capacity, or can successful policy implementation actually lead to greater state capacity in that particular arena of state action?

The policy process - from elite preference formation in settling on what ought to be done, to mobilization and management of lower reaches of state organization to execute what should be done, to coalition formation with key sectors in society, and to communication about the new rules of the game to wider publics - remains surprisingly opaque and delinked from this larger problem of building state capacity. In deeply rent societies coming out of long periods of militarized conflict through either civil war, invasion, or decolonization, it is often imperative for aspiring state 
builders to engage in all of these activities simultaneously. Worse, they must typically do so under conditions of unproven capacity, extant state organizations of questionable loyalty, sectors of society that first need to be defined and organized in order to be favored or discriminated against, and norm dissemination to societies that may well be suspicious, fearful, and cynical about the deployment of state power. Thus how aspiring state-makers conceptualize what ought to be done, understand what is possible within the structural constraints of the resources (human, economic, and infrastructural) in which they operate, and adopt strategies for implementing their preferences under conditions of limited state capacity is as important as it is understudied. Political will from above is a necessary but insufficient element of successful policy implementation. Implementation of new core programs ultimately depends on mobilizing the commitments of those in relevant state organizations lower down, and success in either enlisting or bypassing the sectors of society most affected.

In order to explore the processes within the "black box" between preference formation and policy implementation, this chapter compares the land-reform programs implemented in the early years of regime consolidation in the People's Republic of China (PRC) and the Republic of China (ROC)/Taiwan in the early I950s. While we are now used to thinking of the PRC and the ROC/Taiwan as examples of particularly capable states in terms of their promotion of rapid development, few would have predicted these successes in 1950. In the middle of the twentieth century, China was desperately poor, politically and socially fragmented, and in a state of economic collapse. This was not surprising, given that China had also undergone more than a generation of almost ceaseless militarization and warfare. The one-party states that arose over the course of this grim historical sequence were the "revolutionary" People's Republic of China, which won the Chinese civil war, and its rival "conservative" Republic of China, now relegated to the backwater of island Taiwan. The PRC and ROC/Taiwan stand as exemplars of two supposedly diametrically opposed approaches to state-building - the revolutionary and mobilizational versus the conservative and top down. Yet, in the early I950s, each staked a huge amount of its legitimacy on the successful prosecution of land reform, and both were by any standard successful, despite the extraordinary challenges they faced in so doing.

I suggest that the reasons for this success lie in the way each deployed two key modalities of administrative policy implementation: (I) the "bureaucratic" and (2) the "campaign." The bureaucratic mode is the stuff of 
which "state institutions" are made: formal organizations, hierarchical lines of authority, rule making, and rule implementation. It is heavily precedent-oriented, and impersonal, as the same rule by definition is applied to the same categories of people, things, or situations. The campaign is defined by a delimited period of intensive focus on a particular program or set of goals. It is launched by political elites, is implemented by state organizations, and then spreads by varying degrees into society. In contrast to the bureaucratic modality, campaigns are by definition extraordinary. They seek to engage emotional commitments, often sidestepping or overriding the procedural and rule-bound. They may spread beyond the bureaucracy to engage and mobilize significant segments of the population, with unpredictable consequences. Despite these profound differences in mode of implementation, campaigns cannot completely undercut the formal institutions of the state and their well-known tendencies to hierarchy, formal structure, and precedent-based rule making; after all, campaigns require committed state agents to run the campaign. In policy environments in which "regular" bureaucratic functioning is insufficient, the very process of implementing a focused campaign condenses and accelerates normally sequential processes (preference formation, coalition creation, bureaucratic mobilization, and wider norm dissemination). Under these conditions a well-executed campaign can serve to dramatically expand state capacity by simultaneously firing up the commitments of state agents, expanding their numbers, and lowering social resistance to regime programs. Conversely, an unsuccessful or damp-squib campaign can fail to organize, mobilize, and engage the commitments of implementers and end users alike.

\section{THE “TWO CHINAS” AND THE “NECESSITY” OF LAND REFORM CIRCA I950}

This chapter considers the state's dramatic campaigns of (re)distribution through land reform in two particular geographical regions of greater China in the early I950s: (I) China's Sunan region south of the Yangzi River, centered on Shanghai, which was then (as now) the wealthiest area of the People's Republic of China, and (2) the island of Taiwan, to which the vanquished Nationalist (Guomindang, GMD) government had retreated following its defeat in 1949. At the time of land reform, communistdominated movements of national liberation had either marched to victory or seemed to be on the verge of doing so in China, Korea, and Vietnam. By mid I950, the outbreak of the Korean War had prompted US aid and 
support to shore up noncommunist competitor regimes. All were, with good reason, obsessed with internal and external security.

There was little reason to be sanguine about either the PRC or ROC/ Taiwan in 1949-50. Both were highly militarized party-states that ruled primarily by coercion. Neither possessed a capable, well-run civil service, and both had very shallow roots in local society. The Chinese Communist Party's long years of revolutionary struggle in the impoverished countryside of north China meant that it had little to no penetration of city or countryside in central, south, and west China, where it came in as an army of occupation. For its part, the Guomindang on Taiwan had so thoroughly mismanaged "recovering" the island from Japanese colonial rule after 1945 that within two years it found itself having to quash an island-wide uprising. In 1949 it was widely despised by local Taiwanese as corrupt, brutal, and alien. Within four to five years, though, each of these Chinese regimes was well consolidated, solidly aligned on opposite sides of the bipolar international system, and on an accelerating trajectory that made it an archetypal case of either radically revolutionary state making from below or conservative-controlled state making from above. The "successful" land-reform campaigns of the early I950s, and the ways in which they were written into contemporary justifications of regime legitimacy illustrate in microcosm how the very process of implementing land reform strengthened the state organizationally, demonstrated regime legitimacy and commitment to social justice, and instructed the population into its core values.

Whether draped in the rhetoric of either the PRC's popular mobilization and mass revolution or the ROC/Taiwan's restorationist conservatism, state-makers in the new People's Republic and the not-so-new but now revitalizing Republic of China/Taiwan, held in common a core of state-making agendas that was deeply authoritarian and fundamentally transformative. While both ruled by coercion, each was eager to build up alternative sources of legitimacy, silence real or presumptive enemies, garner the acquiescence of core social groups, and fundamentally reorder rural relations. This agenda in turn required additional state capacity to (I) remove all sources of real or imagined opposition to regime initiatives, (2) create a range of state institutions that systematically subsidized and privileged the urban over the rural while not appearing to do so, and (3) communicate a new political language and set of norms to the population at large. For both moral and instrumental reasons, land-reform programs were an integral component of this wider agenda. Ensuring a modicum of social justice in the countryside through redistribution was an intrinsic 
moral imperative: The failure to have done so was widely understood to be why the Guomindang lost the civil war. More instrumentally, meaningful land reform could break the power of sitting rural elites, allow the regime to penetrate to the grassroots of the countryside, and pave the way for the reorganization and reincorporation of the countryside on terms determined by the party-state.

\section{CAMPAIGNS AND STATES: REPERTOIRES OF INTENSIVE IMPLEMENTATION}

Translated into English as "[social] movement" or "campaign," the term "yundong" is fraught with ambiguity. In China's Republican period (I9II-49), yundong denoted two very different phenomena: (I) social movements from below that challenged state weakness in the face of external imperialist pressure, and (2) communist and Nationalist efforts in party, military, and state organizations to intensify focus and implementation around particularly defined objectives. After 1949, the term came to be almost exclusively associated with the People's Republic of China as the revolutionary regime trumpeted its successful Three Great Campaigns (against US involvement in the Korean War, against "counterrevolutionaries," and for land reform), in establishing a "mass line" uniting mobilized masses with the government. In contrast, the ROC/ Taiwan government seldom used the term "yundong." In order to distinguish itself from its bitter rival across the Taiwan Straits, the ROC/ Taiwan party-state defined itself in terms of rules, procedures, precedent, and sober regularity. But the ROC/Taiwan's reluctance to use the term did not mean that it did not conduct campaigns.

If the notion of yundong is broadened to mean a period of extraordinary government intensification, drawing on a repertoire of specific practices to enable that intensification, and deploying that extraordinary focus to implement a particular policy, then it is clear that both the PRC and the ROC/Taiwan launched campaigns. These drew on a venerable lineage from the late imperial state as well as the specific practices of Leninist (re) organization from the I920s. ${ }^{.}$There was a spectrum of campaign activity. The minimalist variant simply geared up the bureaucracy for an extraordinary deployment of material and human resources to achieve a particular goal. This sort of campaign (such as the annual push to tax the

\footnotetext{
I For the ways in which the late imperial state used campaigns, see R. B. Wong 20 I 2.
} 
harvest) expected little in the way of mobilization or social change outside the state itself. At the opposite extreme, a maximal campaign, such as the PRC's actions against landlords or counterrevolutionaries, or the Great Leap Forward of 1958 , aimed for a close-to-universal mobilization of society in support of regime goals. In between was a range of different types: Campaigns could be geared to one-time problems (for instance, draining a swamp). Others targeted relatively small and/or easily delimited groups in society who were expected to exhibit major behavioral changes (for instance, campaigns to wipe out prostitution or opium use). At their most limited, campaigns involved bureaucratic gearing up and intensification; at their most maximal, they also led to highly visible full social mobilization in support of regime goals. ${ }^{2}$

Although campaigns presupposed the existence of a cadre of committed state agents, under normal circumstances campaign modalities were inherently in tension with the bureaucratic organizations of the state. Mao Zedong's discomfort with the revolutionary state's tendencies toward bureaucracy may have been legendary, but even in revolutionary China state agents had to be organized vertically into hierarchical and responsive organizations. Insofar as hierarchical state organizations tend toward the complex of behavior that Weber called "bureaucratic" - regularity, impersonality, rule making, standardizing, expertise-dependent, and precedent-driven - the extraordinary intensification, concentration of political and administrative action, and disregard of precedent and rules characteristic of the campaign modality normally undercuts the key features of bureaucratic modalities in state organizations. ${ }^{3}$ But the success of PRC and ROC/Taiwan's land-reform programs in the early I950s suggests that this is not always the case: Under conditions of early regime consolidation an intelligible campaign can indeed expand state capacity through rapid identification, training, and deployment of newly committed state agents to take on extraordinary, heroic roles. In their respective abilities to harness campaign modalities of policy implementation to statebuilding capacity generation, the "revolutionary" PRC and the "conservative" ROC/Taiwan had much more in common than met the eye.

2 Of course, not all campaigns are effective: they can be unfocused or unclear in their intent, involve sloppy training or inappropriate slogans, mobilize those who are unsure of why they are being mobilized, have a host of unintended consequences, or simply peter out because the subjects of a campaign are alienated or bored.

${ }^{3}$ For the classic statement of Weber's conception of bureaucracy, see Weber 1946, 196-203. 
OVERLAPPING AGENDAS AND CAMPAIGN ARTICULATION: WHY REMAKE THE COUNTRYSIDE THROUGH LAND-REFORM CAMPAIGNS (I950-I953)?

The state-making elites of the PRC and the ROC/Taiwan took land reform incredibly seriously. Staking a big part of their legitimacies on its successful completion, both pushed through sharp, aggressive landreform campaigns between 1950 and I953. Both also insisted that the manner in which the campaign was carried out was as important as the result. The first question is why. Land reform as a precursor to collectivization may have been de rigueur in the early regime consolidation of Marxist-Leninist regimes the world over, but outside Japan and South Korea, where land reform was implemented in whole or in part by the US military, why did a "conservative" regime aligned with the United States implement a meaningful land-reform program rather than simply pay lip service to the notion? The ROC/Taiwan state amassed both the political will and the administrative capacity to push through a serious landreform redistribution in a way that other "conservative" regimes of the time (such as the Philippines and Thailand) did not. The typical factors cited to explain the ROC/Taiwan's commitment to and successful implementation of land reform include Taiwan's small scale and the ruling GMD's lack of political obligation to the Taiwanese landlord class in the countryside. While entirely sensible, this line of reasoning does not quite explain why Guomindang felt it so important to visibly demonstrate its effectiveness in land reform in Taiwan, or why it took such pains to distinguish itself and its tactics from the ongoing land-reform campaign in the PRC. Similarly, once the Chinese Communist Party (CCP) began to push through land reform in Sunan in 1950-5 I, why was it so insistent that land reform in central China replicate not just the required outcome, but the actual processes of earlier experiences in north China of "making revolution" through popular mobilization, free-flowing emotion, and public demonstrations of popular support? ${ }^{4}$

The rationale for these deep attachments seems to lie in the way in which political leaders interpreted the successes and failures of their recent histories. Despite their differences on the question of class struggle, the political leaders of these rival Chinese governments subscribed to a complex of overlapping notions for legitimate state action that derived

\footnotetext{
${ }^{4}$ See W. Hinton I966; Crook and Crook 1968.
} 
from a much longer tradition of imperial statecraft and agrarian empire: (I) an assumption that properly socialized and motivated state administrators are able to overcome objective circumstances through proper application of morality and will, (2) a deep suspicion of any associational activity not overseen and deemed legitimate by the state, and (3) a normative commitment to the state's role in ensuring subsistence and approximate social justice.

The PRC's and ROC/Taiwan's rhetorical framings and relevant diagnoses of rural problems that "demanded" land reform also converged with the dominant global developmental norms of the mid twentieth century. Whether Leninist/revolutionary or liberal/modernizing, all shared a distaste for the "inefficiency" of smallholder-based, "fragmented" agriculture and professed an affinity for the big, visible, and noticeable projects emblematic of mid-twentieth-century modernity: concrete, dams, infrastructure, and factories. Each further assumed that the state had to extract as much as it could from agriculture to finance industrialization and other modernization projects. Both diagnosed the key ills of China's agricultural hinterland to be economic stagnation, severe inequality, fragmentation, and pressure on landholdings. Therefore, land reform was essential for immediate social justice and the further economic development that only increases in agricultural productivity could bring about.

Discussion of land reform was framed by the presumption that it was economically desirable (to lay the groundwork for further consolidation and efficiency in agriculture), socially necessary for equity, demanded from "below," and politically paramount: Indeed, the very legitimacy of the regime in the countryside was presumed to depend on its successful implementation. These propositions were extrapolated from the Chinese Communist Party's own relatively successful experiences with making revolution in the impoverished countryside of north China in the late I940s. All were also highly questionable when applied to the much wealthier and more diversified rural economies of Sunan and Taiwan, where tenancy was already in decline, landlords were weak, and migration to urban areas in search of factory work was well established. What mattered for these campaigns were the perceptions of necessity, social justice, subsistence guarantees, and legitimacy that framed land reform for state-building elites. ${ }^{5}$

5 These assumptions can be found in virtually all of the propaganda on the importance of land reform in both China and Taiwan, as well as by Westerners able to observe the prosecution of land reform in north China villages in the late I940s. See Pan I95 I, I98; Shi I95I, 88-89. See also W. Hinton I966; Crook and Crook I968; Chen I960; and Tang I955. 
Despite their significant differences in ethos (violence vs. inclusion), type of implementing organization (class-based revolutionary party vs. technocratic administration), and official rate of implementation (speed in China and deliberately slow sequencing in Taiwan), the trajectory of land reform's campaign implementation in Sunan and Taiwan was broadly similar. The steps consisted of: (I) a preparatory stage that involved meetings, internal information dissemination, and training of extraordinary numbers of staff to implement the campaign, (2) intensive propaganda aimed to educate the rural population about the necessity, desirability, and mechanics of the program, (3) the creation of local representative organizations (peasant associations in the PRC and rent-reduction committees later transformed into farmer/tenant committees in Taiwan) to support the campaign, $(4)$ the intensive assessment, checking, and official recording of who owned what land, backed up by the dispatch of outside leaders to guide and check on this process, $(5)$ the actual redistribution of "excess" land to those in officially designated land deficit, and (6) review and rechecking of the results.

The content of the early to middle stages of land-reform campaigns was also nearly identical: Both vastly expanded state capacity by recruiting and dispatching newly deputized state agents to the countryside. The implementation of policy required generating substantial amounts of new state capacity. Conducting preliminary investigations, generating and revising records, creating and disseminating enormous amounts of educative propaganda, and soliciting popular rural support for the program while retaining full control over both process and outcome did not happen automatically. These elements of land-reform campaigns occurred because the state concentrated organizational effort and resources to (I) expand the size of the bureaucracy and (2) lower social resistance to the land-reform program. In both Sunan and Taiwan, this meant training very large numbers of people, often young, to go down to the most grassroots level of the countryside to aid implementation. In Sunan, land reform went hand in hand with a substantial expansion of the ranks of basic-level cadres in the countryside. In the Shanghai suburbs alone, some 460 lecturers from local universities and middle schools were trained and sent to the countryside to implement land reform, accompanied by 4,6I6 activists, largely from poor peasant backgrounds. Once in the countryside, a substantial minority never left; more than one-fifth $(\mathrm{I}, \mathrm{O} 42)$ of these activists were eventually regularized as permanent cadres then entrusted with running later rural campaigns. ${ }^{6}$ For

${ }^{6}$ SMA (Shanghai Municipal Archive) B B $4 / \mathrm{I} / 80$, "Shanghai shi jiaoqu xunlian ganbu shu peiyang jijifenzi qingkuang" (The situation for Shanghai municipal outer district cadre 
the wider Sunan region, the Sunan Party Village Work Committee targeted the training of an eventual II,333 cadres to cover the three districts of Suzhou, Changshu, and Songjiang. ${ }^{7}$

Similar training exercises took place in Taiwan under the auspices of the Joint Commission on Rural Reconstruction (JCRR), which was a small agency for rural development jointly run by Americans and Chinese agricultural economists. Its function was to draw up plans and provide training for local Land Bureaus (dizheng $c h u$ ) under the auspices of the Taiwan provincial government to extend their reach down to every village and hamlet. The JCRR oversaw the training of more than 4,000 staff workers to implement a rent-reduction program (sanqiwu) between I949 and 1952. It repeated the exercise in 1952 when it trained an additional 2,000 people to carry out the specific technical work of checking and reentering of landownership record cards for the entire cadastre of land under cultivation on the island in preparation for the Land to the Tiller program of 1953 (gengzhe you qitian). ${ }^{8}$ The culmination of land reform with the Land to the Tiller initiative also required top-up training of administrators already in place in Taiwan's Land Bureaus at provincial, county, and district levels. Provision was also made for supplementary technical training for an additional 2,400 field workers, and extra training of the 3,000-odd members of local Farm Tenancy Committees and 6,537 hamlet and section chiefs. ${ }^{9}$

The state also put a great deal into propaganda. This meant persuading large numbers to mobilize in support of the state's program to go down to the countryside to convince rural populations that these new policies were reasonable, comprehensible, and absolutely necessary. Publicity about land-reform programs was disseminated widely in the national, regional, and local press. In Sunan pamphlets were reproduced in simple language, often with use of cartoons, laying out basic questions and answers to illustrate the gravity of exploitative feudalism in the countryside and the

training and the cultivation of activists), and "Sheng tudi gaige qianhou xiangcun jiceng ganbu bianhua qingkuang tongjibiao" (Statistical form on changes in village level local cadres before and after land reform), both p. I 3 of internally numbered file, dated Dec. 3 I, I95I; SMA BI4/I/6, "Jiaoshi canjia tudi gaige di'yi xiaozu mingdan ji duiyuan tongjibiao" (Instructors participating in land reform: the first small group name list and statistics), I95I.

7 JPA (Jiangsu Provincial Archive) 3006-3-360, "Benhui [zhonggong sunanzu dangwei nongcun gongzuoweiyuanhui] Sunan ganbu xunlian tongjibiao" (Chinese Communist Sunan group party village work committee Sunan cadre training statistics), I950.

${ }^{8}$ Tang I955, 50-5I. 9 Ibid., II 6. 
government's measures for resolving this deplorable situation. ${ }^{\mathrm{IO}}$ More upmarket versions of printed propaganda were aimed at intellectuals. In the spring of $195 \mathrm{I}$, Pan Guangdan and other senior academics from Beijing were taken on a study tour of land conditions and the process of land reform in Sunan. The resulting publication reads as a conversion experience: being awakened to the suffering of the peasantry and deep inequality in the countryside, the correctness of the CCP's categories of class analysis, and absolute support for the notion that the evils engendered by feudalism required total overthrow by the Chinese Communist Party. ${ }^{\text {I }}$ Finally, propaganda was taken straight to the villages with small group meetings, and popular entertainment featuring plays emphasizing the drama and righteousness of land reform, further blurring the boundary between education and entertainment. ${ }^{\mathrm{I} 2}$

Given the virulent ideological hostility between the two regimes, propaganda dissemination in Taiwan was astonishingly similar. In preparation for the Land to the Tiller program, the JCRR's itemized budget for project publicity was even larger than its training budget. Specific forms of propaganda and publicity, and means of dissemination, were nearly identical: Cartoons, movies, songs, and plays accessible to rural villagers were commissioned and then intensively deployed. Once written and rehearsed, these dramatic performances were scheduled to be performed at the rate of one per every three villages throughout Taiwan. The JCRR subsidized the projection of a reel of educational slides about the Land to the Tiller program to be run in more than $\mathrm{I} 20$ cinemas. The JCRR also blanketed the island with paper that explained, exhorted, and entertained; fully half of its large printing budget was devoted to publicity materials, many of which entertained as much as they informed: cartoons, movie synopses, posters, pictures, and the texts of the locally performed plays along with more mundane copies of program regulations. ${ }^{\text {I3 }}$

DIVERGING CAMPAIGN REPERTOIRES I: PLANNING THE SHOW

The CCP and the GMD are normally thought to be utterly unalike because of their sharp differences on class struggle and physical violence,

ro See Tao and Wang I95I. $\quad{ }^{\text {II }}$ Pan I95I. ${ }^{\text {I2 }}$ Xiao I950.

${ }^{13}$ GSG (Guoshi Guan [Academia Historica]) 3I3/I28 5-3 FY 52, "A Preliminary Budget Estimate for the Private Land Purchase Project in Taiwan," prepared by Taiwan Land Bureau, April 1952. 
and it is certainly true that this basic philosophical difference was at the core of the ways in which these two regimes' repertoires diverged over the course of land reform. The CCP trumpeted the cleansing power of struggle, including physical violence, while the GMD shied away from explicit struggle whenever possible, preferring to conduct its violence out of sight. The CCP explicitly and deliberately used land reform as a way to engage in a project of investigation and classification of the countryside, fixing class labels on the basis of occupation for individual families that would remain permanent; the GMD made every effort to encourage individual movement between different occupational statuses (from tenant to freeholder, and from landlord to state capitalist). ROC/ Taiwan political elites went to extraordinary lengths to distinguish themselves and their land-reform programs from the violent and evil Other on the opposite side of the Taiwan Straits. This was implicit in the rhetoric, but it was also explicitly laid out in private discussions within the government.

One ROC/Taiwan Executive Yuan internal meeting went as far as to lay out the parameters of the conceivable for land reform. As the purpose of the Land to the Tiller program was "to abolish an irrational system of tenancy, to establish an open and fair system of private landownership, and to return landownership to the tiller," a chart was made up on an oversized paper that was folded in on itself several times. The key features of the communist land reform were listed on the left side of the paper, the range of possibilities for the Nationalist version on the right. Throughout, the possible options were negatively framed by the (presumed) goals and repertoires of the communists: If those awful "gongfei" (communist bandits) over there had engaged in class struggle and public humiliation of landlords, then by definition we good and pure people over here could only consider methods that explicitly ruled out class struggle and public humiliation of landlords. If the communists had done $\mathrm{x}$ and $\mathrm{y}$, then we could only countenance engaging with what was clearly and demonstrably non-x and non-y. For the Guomindang, the range of the imaginable for land reform was explicitly defined in terms of what the CCP had not done. ${ }^{I 4}$ These different choices not only expressed core philosophical differences and bitter competition. They also were part of a much larger process of mutual differentiation through visible, public performances

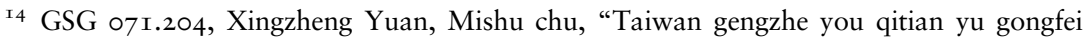
'tugai'" (Taiwan's Land to the Tiller and Communist Bandit "Land Reform"), August 2, I953. 
that reified each regime's own way of doing things while instructing the population at large into that state-mandated good.

The actual performances of land reform in the two Chinas differed in pace, staging, dramatic register, and the sorts of popular participation solicited. In Sunan, land-reform performances necessarily required very public forms of participatory theatre that were acted out in public space through mass gatherings that were called variously "struggle meetings" (douzheng hui) or "accusation meetings" (kongsu hui). Local cadres who failed to "stir up the masses" (fadong qunzhong) were severely criticized by their superiors, because one of the main goals of popular mobilization was to socialize the population into new regime norms by having the masses be stirred to active participation. In Taiwan land reform was equally heuristic, but its land-reform performances demonstrated legal procedure and due process. In Sunan, mass yundong required the fear and anger of cathartic mass emotion; the graphically corporeal destruction of the "old" (feudal, corrupt) as a form of cleansing and public identification with the "new" (modern, clean, and bright), now firmly identified with the CCP's right to rule and the legitimacy of the PRC. In Taiwan, the ROC government, in cooperation with the JCRR, made every effort possible to mobilize and channel emotion through procedures, best exemplified through highly controlled public voting exercises.

In order to support these two different conceptions of what the stateenlightened subject was supposed to do, land-reform campaigns engaged publics in very different ways by putting on very different sorts of shows. The first major difference was in pace. From beginning to end, land-reform campaigns in Sunan took roughly eighteen months and concluded with a mandatory "high tide" (gaochao) of particular intensity. In Taiwan, landreform campaigns lasted five years, and were designed to be deliberate technical exercises.

In Sunan, official investigations into rural conditions and land reform in experimental villages (shidian cun) dragged on throughout 1950. During this trial period, it became clear that many local cadres doubted that the land-reform campaign was necessary. The class categories of exploiters and nonexploiters that had served as such potent mobilizers in north China made little sense in wealthy, diversified Sunan, where those who felt "exploited" had a habit of searching for, and finding, work in factories in the city. The presumed reservoir of mass hatred for rural "exploiting classes" was embarrassingly deficient. Many peasants resolutely refused to be "stirred up" and instead sympathized with the putative "exploiters" in their midst. Given the large disconnect between 
rural Sunan's conditions and the categories handed down from above, many local cadres were initially reluctant to go out and stir up social hatred against an exploitative class that did not exist. This noncompliance was broken in November 1950, when the entire Sunan region sent cadres to a specially convened land-reform conference in Shanghai, where local officials were put on notice that their excuses and foot-dragging would no longer be tolerated. Predictably, the campaign then lurched wildly to the left. The actual "high tide" of the campaign with its full repertoire of mass meetings, public accusation, and assignment of the "fruits of struggle" was conducted at different times throughout Sunan, but once underway it was invariably pushed through extremely quickly.

The description below of land reform in Qingpu county, to the immediate west of Shanghai, is indicative of how the campaign was implemented in Sunan: "[B]y the end of August [1950], each district had seven experimental areas that had implemented land reform; in the first half of September the second group of twenty-seven villages and one town began ... by the end of November, the entire county had finished up."

Land-reform work went through the training of backbone (cadres), propaganda mobilization, and division of classes. The county party committee held three land-reform cadre training sessions that 45 I cadres attended, of whom 96 were land-reform work team members who were sent to help with land-reform work in villages after participation in the district experimental villages. The county Peasant Association convened four Peasant Representative Meetings with 3, I I 7 participants; IO,500 participated in district-level Peasant Representative Meetings, which disseminated propaganda about the significance and purpose of land reform:

In the middle of land reform, the districts held a total of $\mathrm{I}, 072$ public accusation meetings; I 37,000 participated, and [of these] 3,855 individual peasants uncovered and accused landlord and evil bullies' criminal behavior ... 332,069 mou was taken from landlords, and the remaining $105, \mathrm{I} 58 \mathrm{mou}$ from half-landlord half-rich peasants, rich peasants engaging in trade while renting land, petty rentiers, and other kinds of public land. According to policy, this land was distributed to poor peasants and hired laborers, middle peasants, and others engaged in labor. In order to transform landlords into self-supporting laborers, they were given a parcel of equivalent land. Undergoing the process of land reform has realized "land to the tiller" [gengzhe you qitian]. Land reform ... through public meetings also redistributed landlords' excess property of 426 carts, $37 \mathrm{I}$ boats, 370 head of water buffalo, 2, I 56 pieces of furniture, 4,786 dwellings, and $540,000 \mathrm{~kg}$ of grain to poor peasants and hired laborers. On May I 5, I95 I, the county government promulgated "land-reform house-ownership 
certificates" (also called "land-reform certificates"). These were distributed in three batches, concluding at the end of July, with the issuing of more than 6I,000 certificates. ${ }^{15}$

This official report makes it clear that the CCP put a premium on speed. Once begun in a particular locale, mobilization, propaganda, mass accusation meetings, and redistribution appear to have been condensed into one intensively charged period of approximately two weeks. In the Shanghai jiaoqu (outer districts), and in rural Shanghai county to the south of the city, land reform was delayed until the spring of 195 I but, once underway, "high tides" were of even shorter duration. In Shanghai county these "high tides" took on average a week, and in some cases were completed within only four or five days. ${ }^{16}$ Final registration of the results, record keeping, and the hearing of appeals and resolution of difficult cases and border adjudication dragged on into I952, but these were relatively simple matters of bureaucratic tidying up.

The comparison with land reform in Taiwan is stark. In Taiwan the architects of land reform went out of their way to adopt a gradualist version of land reform. Ex post facto accounts of the land-reform process suggest that land reform was accomplished via four carefully planned and executed projects that progressed in natural sequence between I949 and I953-54. ${ }^{\mathrm{I7}}$ Officially, the JCRR and the Nationalist government jointly developed land reform out of four quite separate and deliberately gradual administrative initiatives that built on each other between I949 and I954: (I) the " 375 " rent reduction that limited tenant rents to one-third of the crop (1949, but accelerating in I95 I-52), (2) the sale of public land (I95 $\mathrm{I}-52$ at various points), (3) the rechecking and reregistration of the entire cadastre (1952), and only then (4) the Land to the Tiller program (1953, but comprehensively assessed and declared to be an overwhelming success in I954). The signature Land to the Tiller program was designed to provide "reasonable" compensation to landlords and to proceed incrementally, through a process whereby, after the landlords' compulsory sale of excess land to the state and the state's transfer of that

I5 This and the previous two paragraphs are drawn from Ma 1990, I99-200.

${ }^{16}$ MDA (Minhang District Archive) I3-I-37 "Shanghai xian guqu" (Shanghai county districts). This map shows forty-eight districts in the county, with the dates of their first (preparatory), second ("high tide"), and third ("concluding") phases of land reform. Of these, twenty-three completed the second stage in a week or less, and twenty-three in one to two weeks, none in more than two weeks, and two for which there is no information.

${ }^{17}$ Chen I960, 20; Hsiao I953, 20; and Sino-American Joint Commission 1965, 7-I2, 20-85. 
land to tenants, tenants were to redeem the value of the land through installment payments to be completed over an additional ten-year period. Explanations of land reform stressed its incrementalism, gradualism, and reliance on material incentives. Even after the land was fully redeemed after a decade, land reform was scheduled to then move into a "second stage" of gradual land rationalization and consolidation in a gradual and only distantly realizable future of efficiency and progress. ${ }^{18}$

In practice, land reform in Taiwan was not nearly as cleanly incremental as these official narratives suggest. The apex of land-reform campaigns in Taiwan, the Land to the Tiller program, is best understood as a dramatic campaign of regime mobilization in response to the problems engendered by the state's more vigorous implementation of " 375 " rent-reduction policy in $\mathrm{I} 95 \mathrm{I}-52$. To the dismay of the planners in the JCRR and the Taiwan Land Bureau, rather than lessening social conflict in the countryside, the attempt to enforce rent reduction in $195 \mathrm{I}-52$ triggered widespread evasion, unilateral lease cancellations, waves of disputes between landlords and tenants, and political openings for left-leaning local officials and organizations to claim to be simply implementing the government's policy. Uncertainty over land tenure meant that land prices dropped. Landlords complained bitterly about their sudden economic precariousness. Local Rent Reduction Committees (sanqiwu weiyuanhui) established to resolve disputes between landlord and tenant were utterly ineffective, as they were either landlord-dominated or existed only on paper. In short, a more muscular approach to enforcing rent reduction led to the exact opposite of what it was designed to accomplish: stability in the countryside. Thus the much less gradualist Land to the Tiller program (gengzhe you qitian) was conceived and implemented in a rush to correct these unanticipated results.

\section{DIVERGENT REPERTOIRES II: PERFORMING THE CAMPAIGN}

Violence, either real or threatened, was at the heart of land reform, and this was as true in Taiwan as it was in the People's Republic of China. What differed was how direct or implicit the violence was, its relative (in) visibility, and how it became entangled with quite different forms of representation and local participation. Officials in both Sunan and Taiwan presumed that regular, organized representation from "below"

${ }^{18}$ On this process, which went well into the I970s, see Bain I993. 
was necessary for the successful implementation of such a life-altering program in the countryside. Each made efforts to organize the grassroots through popular election into Peasant Associations (for China) and Rent Reduction Committees/ Farm Tenancy Committees (for Taiwan). The formal Peasant Associations in Sunan were, however, typically bypassed in actual decision-making. Although set up by the Chinese Communist Party, Peasant Associations were distrusted on the grounds that they could easily come to be dominated by rich peasants and landlords. In at least one documented case in Miaoyang, Changshu, the "masses" openly wondered why landlords could not join Peasant Associations and stand for election as small group representatives. ${ }^{19}$ The Qingpu gazetteer cited above suggests implicitly that land reform in Sunan was implemented by a combination of actors: a local land-reform committee (often led by outsiders appointed by the county government), external work teams, cadres sent to the county seat for special training sessions, and pre-identified local activists. ${ }^{20}$ The Peasant Association role appears to have been confined to propaganda dissemination and helping to get everyone to public struggle meetings.

In Sunan, local participation in land reform was articulated through a form of direct collective response unmediated by rules and procedures in the public drama of mass struggle sessions. The CCP campaign repertoire required a "high tide" (gaochao) in which the masses were stirred to action. And the only action that would do was a public mass chorus that would articulate rightful hatred toward landlord exploiters. The revolutionary state deemed this necessary as a first step in raising popular revolutionary consciousness, explicitly engineering a public rally around the new government and garnering the public's collusion in bloody violence against the state's newly defined enemies.

Despite their seeming spontaneity, mass struggle sessions were carefully planned in advance by local state actors. Cadres identified and rehearsed activists and particularly sympathetic accusers (the very young, the very old, women, and the obviously infirm and handicapped) in when to come forward onto the stage of the mass struggle session, and which particular accusations to make. Land reform in Sunan followed performance scripts handed down from higher levels, and there was pressure from on high to repeat the drama and emotionally led self-transformation

I9 JPA 3006-3-37I, Sunan tugai weiyuanhui mishuchu, "Guanyu fadong qunzhong wenti de baogao" (Report on the Problems of Stirring Up the Masses), I95 I.

${ }^{20} \mathrm{Ma}$ 1990, I99-200. 
deemed to be necessary to a "high tide" for it to "count" as successful. Cadres at the Sunan regional administration were insistent that the specially chosen wronged "mount the stage" (shang tai) to engage in direct "face-to-face" (mian dui mian) accusation and that the evil accused "publicly acknowledge" previous crimes (chengzui) before the masses, "[as] ... without this kind of public acknowledgment of crimes the entire [process] is fake." ${ }^{21}$ The form of the mass accusation session gathered virtually the entirety of the rural population as a unitary participant-spectator audience, where the specific theatrical device of "speaking bitterness" (chiku) was acted out by precoached activists and victims, and the "masses" publicly merged as one with the state.

Records from Qingpu county, Shanghai county, and the Shanghai outer districts confirm that large numbers of mass struggle sessions were convened and that the "targets" predetermined to be the most evil and hated were promptly and publicly led off to the execution ground. Statistics from Shanghai county convey the startling information that nearly a third (224 of 779) of recorded "accusation targets" (douzheng duixiang) were "strung up and beaten" (douzheng zhong bei diaoda) during the course of these mass accusation sessions. Whether the state's extreme violence against those it labeled enemies of the revolution was welcomed is difficult to determine. The record in Sunan is at present lacking in the kind of detailed eyewitness accounts that convey whether public accusation meetings were genuinely popular, if they brought about the free-flowing tears and spontaneous accusations that featured in the land-reform campaigns of north China, whether they were the product of a small minority, or if in fact they took place only with the connivance of local cadres.

A critical report on the difficulties of stirring up the masses compiled by the Sunan Land Reform Investigation Unit in April I95 I suggests that in many locales cadres had to overcome a great deal of natural reluctance on the part of the "masses" to be "stirred" to physical violence. In one case in Jiading county, Mawei district, Beiguan village, a local cadre clearly incited the crowd to demand physical violence: From the middle of the throng he shouted "go ahead and hit [the accused]." "From the stage [where the accused and a peasant who was 'speaking bitterness' toward the accused were standing], the district cadre instructed the man who was 'speaking bitterness' 'if the masses say "hit him" then you have to go

${ }^{21}$ JPA 3006-3-27I, Sunan tugai weiyuanhui mishuchu, "Guanyu fadong qunzhong wenti de baogao" (Report on the Problems of Stirring Up the Masses), I95I. 
ahead and hit him.' But the man demurred from his appointed role to 'speak bitterness' with the repeated insistence that: 'I've never hit anyone before, and I will not hit him.' As the crowd continued to bay for physical violence, the designated accuser on the stage hit the accused, ultimately resulting in seven or eight blows." 22 In other places, local cadres dampened down the physical violence of accusatory theatre rather than ratcheting it up. In Kunshan's Yebi district, Yebi village, before the public accusation session commenced, the cadre warned the gathered crowd that "he [the cadre] was the one passing judgment, and that anyone who went ahead and 'strung up and beat' an accused target would have to take responsibility for so doing." In another instance involving a particularly despised "little tiger" (xiaohu), a local cadre by the name of Zhang Zhihua refused to let the prisoner go to his appointed struggle session on the grounds that, if the prisoner had to face the public, he would definitely be beaten to death. ${ }^{23}$

Statistics claim that the majority of the rural population "participated" in accusation sessions, but these were the aggregate numbers of those who turned up for the public gathering. Formulaic reports uniformly conclude that "the masses were stirred up" and that justice was done, with resounding affirmation for the state's violence against class enemies. More-detailed micronarratives suggest a much more mixed picture. Some of the presently available accounts support the notion that the land reform's lurch leftward after November 1950 resulted in local cadres who connived with activists to incite the "masses" to publicly denounce and commit violence against chosen "targets." Other evidence suggests that local cadres limited the degree of uncontrolled violence that they would permit on their watch. Within this variation, however, it is clear that scripts handed down from superiors required a dramatic culmination of "stirred-up" masses accusing evil landlords and reaffirming collective unity with the state and its violence against defined enemies. Sometimes the public performance went well. In other cases it seems to have not, given that in Sunan the dividing line between exploited and exploiters was blurred, landlords were weak, social and economic mobility was high, and in many places local people actually thought that their own local landlords were not such bad sorts at all. We cannot know for sure about something so variable and subjective, but it does stand to reason that perhaps the masses were less enthusiastic than the large numbers of those

22 JPA 3006-3-27I, “Guanyu fadong qunzhong douzheng de cailiao zhailü,” April I95I.

${ }^{23}$ Ibid. 
in attendance at the mass struggle sessions would otherwise suggest. The dramatic dénouement of state led retribution through public accusation meetings followed the form laid down in north China in the late I940s, but how well the repertoire of staged private suffering, spontaneous violence, and cathartic emotion played in the very different environment of Sunan is still an open question.

The young PRC deliberately used theatre, and theatrical metaphors, to describe this necessary "high tide" in the land-reform campaign. Meaningful local input came into the process on what was literally a (makeshift) stage, and popular participation was theatrically expressed in ways that were diametrically opposed to the procedural and regularized forms of participation in land-reform campaigns in Taiwan. In Sunan, the public nature of the staging, the unitary and emotional narratives of prior suffering, the visibly shackled representatives of evil personified encouraged the very reverse of procedure and rules - an unleashing of collective emotion and fury that merged individual interests into collective identification with the group and the new regime. Although these were in fact heavily stage-managed events, and the spontaneity of the accusations levied and the importance of the crowd in determining the outcome toward the accused were more apparent than real, it is not at all clear at this early stage in regime consolidation that the "masses" understood that the outcome of public struggle sessions was foreordained and that their designated role was that of the chorus: to be stirred to emotion, to cheer and clap on cue, and to collectively reaffirm the moral righteousness of the regime in stamping out vicious enemies. The mass struggle meeting was as much a heuristic device for educating the participants about the new regime's norms and rhetoric as it was a means for dispatching individuals deemed to be enemies of the state. The state claimed to represent, reproduce, and make public the legitimate position and opinions of "the masses"; the masses in turn learned what was expected of them through in collective action in new forms of political participation unmediated by organizations or procedures. The staged public form of the mass struggle session implicitly bloodied the hands of all of those who shouted in support of the regime's violence against enemies, and provided a symbolic point of no return. After such a highly charged show of participatory violence against defined class enemies, things would never be quite the same again. When the show went well, local participation and representation were thus articulated through a publicly affirmed merging of crowd and state; representation was fused in a dramatic unity with the state and its agents. 
Local participation in land-reform campaigns was equally important in Taiwan, but it could not have been more differently articulated. Rather than emotional "stirring up" free-flowing tears and violence, provision was made from the outset to carefully mobilize and strictly channel participation in highly regularized, indirect forms of procedural representation. Land reform in Taiwan promoted two forms of this kind of representation: Rent Reduction Committees (sanqiwu weiyuanhui) (1949-5I), which were replaced with much stronger Farm Tenancy Committees (gengdi zudian weiyuanhui) in 1952 . The Rent Reduction Committees never worked as intended and either did not meet at all or became vehicles for continued elite domination. In 1952, the combined JCRR-government response was to establish an islandwide series of Farm Tenancy Committees to replace the Rent Reduction Committees. This was accomplished through another, quite literal kind of subcampaign: to hold islandwide indirect elections to these newly established Farm Tenancy Committees. Thus, what was not fit for purpose was replaced with a very different kind of theatrical performance: the theatre of the public, competitive election, followed by the more closed and bounded performance of procedural rule application by the elected committee behind closed doors.

The first round of elections for Farm Tenancy Committees was for hamlet and section representatives. First a list of eligible voters was compiled on the basis of rural occupational status (landlord, tenant, or freeholder). Regular village and township offices screened the applications of prospective candidates and then publicly displayed the list. From this public posting, each hamlet and section elected two tenant-farmer representatives, one owner-farmer representative, and one landlord representative. This process was then repeated for the township, county, and municipality, with the total number of committee members slightly weighted in favor of tenants. ${ }^{24}$

A good deal about these elections is unclear. We do know, however, that after these open elections the new Farm Tenancy Committees worked very closely with state bureaucrats in the Taiwan Land Bureau, which gave compulsory two-week training courses to recent electees "to acquaint them with their functions and responsibilities and the relevant laws and regulations." ${ }^{25}$ The head of the local Land Bureau served as an ex officio member of the Farm Tenancy Committee, and its decisions and

\footnotetext{
${ }^{24}$ Tang I955, 56-58; Walinsky I977, 95. $\quad{ }^{25}$ Tang I955, 59.
} 
minutes were reported to the Land Bureau up a level. Difficult cases were passed up to higher-level Farm Tenancy Committees, the district-level dizheng chu, and more rarely the courts.

While much work remains to be done to ascertain the degree to which these Farm Tenancy Committees had real rather than nominal power, it is indisputable that a very large number of elected representatives $(3,032)$ were returned to staff these committees in the second half of 1952 . These local committees met regularly from I953 through the late I950s at least. They had the authority to directly question those bringing the case and those being accused in a quasi-judicial setting. And they formally handled and made decisions on a very large number of adjustments to landclassification and land-related disputes. By one count between January I952 and July I956 township-level committees alone conciliated 31,759 disputes and referred 16,462 to the prefectural or city land-tenure committee. Of these $16,462,9,4 \mathrm{I} 8$ were conciliated and only 5,32I were referred to courts. Other evidence suggests that, within a fairly short period of time, Farm Tenancy Committees began to take on larger roles in local land disputes. For example, in 1955 , a land dispute between the sugar factory and the agricultural school in Yongkang, Tainan, was brought before the Yongkang Town Farm Tenancy Committee. In an echo of the way in which the late imperial Chinese state dealt with local problems, the Guomindang's preferred strategy was to blur the boundaries of state and society by creating a committee of local stakeholders to get them to take over some portion of the state's work. The Guomindang party-state went out of its way to provide for an institutionalized and procedurally oriented form of participatory representation for local interests, with the bonus that this helped manage the workload of adjudicating local land disputes. And, after the public but delimited theatre of the initial elections, this work seems to have been done behind closed doors.

In both Sunan and Taiwan, the state organized local forms of representation to seem as if they represented local popular desires. Both favored particular groups while marginalizing or exterminating others. However, the ways in which the state did so could hardly have been more different. In Taiwan, carefully planned, procedural, and electoral forms of local representation were designed to dampen down emotion. In Sunan public, violent, emotional collective will was deliberately whipped up to merge with the state. In Taiwan the public and participatory elements of land reform were confined to segmented, procedurally oriented elections, after which rules and procedures were delegated to an elected committee, whose deliberations and application of rules occurred in the enclosed 
space of the government office. In contrast, the participatory theatre of Sunan's land reform fused implementation with a temporary but potent emotional high in open public space. It was the campaign's necessary bureaucratic and procedural preparation and tidying up that were hidden from view.

\section{CONCLUSION}

What then, do these revolutionary and reformist variants of land reform suggest for building state capacity in general and implementing redistributive programs in particular? The first, fairly obvious point is that subjective interpretation of what is desirable and possible matters for the mobilization of political will behind a given policy. Insofar as state elites have little immediate material stake, they will find it much easier to generate consensus around redistributive measures. Critical-juncture notions of institutional change suggest that crises and periods of severe irruption (such as after a major war) allow opportunities and spaces for the creation of new practices and institutions. ${ }^{26}$ Crisis and disjuncture, however, do not necessarily or even usually result in redistributive programs and augmented state capacity. One only needs to point to contemporary failure to more seriously regulate banking and credit markets in the wake of the 2008 crisis, or the way in which the crisis of tensions in the new state of South Sudan are as of this writing leading to an escalating cycle of state incapacity rather than leading to the political will and resource commitment to generate new state capacity. Even a cursory review of land reform suggests that there are many more ways in which to fail than there are to be successful. The PRC and ROC were unusually successful in pushing through their own distinctive kinds of performances in land-reform campaigns, but many more regimes at the time - including the Philippines, Thailand, Sri Lanka, India apart from Kerala, and most states in Latin America - did not manage to muster either the political will or the state capacity to implement analogous land-reform campaigns.

The young PRC was dedicated - to the point of obstinacy - to the notion that its campaign repertoire of mobilizational "high tides," faceto-face accusations, and cathartic fusion of state and the masses was a necessary part of revolutionary regime consolidation. Local cadres in Sunan were initially bewildered, but complied. It was only after all the

${ }^{26}$ Pierson 2003; Thelen 2000; Mahoney 2000. 
usual suspects (landlords, bullies, reactionaries, bourgeois intellectuals, capitalists) had been dispatched that these repertoires of public struggle against defined targets began to turn inward, with predictably deleterious effects. One can understand the escalating cycles of radical measures after I954 - culminating with the collectivization campaigns and the disastrous Great Leap Forward of 1958 - as the regime's deep attachment to its signature repertoires of campaign implementation, even under palpably different circumstances than the ones that brought these techniques to the fore. Similarly, the sheer level of political will behind the ROC-JCRR version of gradualist land reform in Taiwan is inexplicable without reference to the ROC's instructively negative counterexperience. The loss of the mainland had been such a searing process for GMD elites that once on Taiwan they engaged in protracted soul-searching, emerging from a set of frank discussions about the causes of their collapse in China with a new consensus about what needed to be done as a matter of regime survival. An absolute commitment to meaningful land reform was inseparable from that new consensus.

Many states limp along with much less than was accomplished in the PRC (revolutionary variant) and the ROC/Taiwan (conservative variant). The case of land reform illustrates how, in two explicitly oppositional regimes, the political will behind a redistributive program was converted into a campaign that simultaneously expanded administrative capacity even as it invited different kinds of public participation and communicated regime norms. And it is here that repertoire and performance become particularly pertinent. Although the particulars of repertoires and performances necessarily vary, if they are comprehensible, justifiable, and command a strong consensus within the higher reaches of the state, they are likely to lead to a stiffening of commitments of state agents, state projection to ever more grassroots of society, and acquiescence in core sectors of society. Insofar as goals are unclear or contested, or repertoires are weakly performed, campaigns launched with even the best of intentions are not likely to result in either policy implementation or increased state capacity. 